\title{
SOME RESULTS OF STUDY ON PRESENT SITUATION OF HOUSEHOLD SOLID WASTE IN HANOI, VIETNAM
}

\author{
To Thi Hai Yen*, Pham Thi Thu Ha, Nguyen The Dong, Trinh Van Tuyen \\ Institute of Environmental Technology, \\ Vietnamese Academy of Science and Technology
}

Kosuke Kawai, Saburo Matsui

Graduate School of Global Environmental Studies, Kyoto University, Japan

Received 14 November 2006

\begin{abstract}
This paper presents some results on the study of Solid waste generated by households (hereinafter referred to as HSW) in Hanoi city. Compositions of the waste generated from three typical communities and their relationship with family life-style of each community were investigated. Differences among compositions of HSW of three resident groups of different incomes, lifestyles were analyzed. Based on the study results, some measures for better management of HSW and maximum reuse and recycle of HSW were proposed. By this way, the amount of HSW transported to landfill could be reduced and stabilization phase of landfill sites could be shortened.
\end{abstract}

\section{INTRODUCTION}

During the last two decades, thanks to the renovation strategy launched by Vietnamese Government, the Country's economy has achieved remakable and stable sucsess with the average growth of GDP of about 7-8 percent per year. Living conditions of the citizens in general and urban residents in particular have been step by step improved with simultaneous changes of life habits and styles. Mentioned changes could be seen through quantitative and qualitative differences among municipal solid wastes generated from three investigated communities, where citizens with different incomes and life styles gathered separately, and then HSW generated from different areas has specific characteristics.

The goal of this study is to clarify quality and quantity of waste discharged from characteristic household groups. The objectives of the study included non recyclable and recyclable waste in Cau Giay district - Hanoi city.

\section{HSW COLLECTION MANAGEMENT IN HANOI CITY}

HSW collection from the urban and suburb areas of Hanoi is mainly implemented by Hanoi Urban Environmental Company (URENCO) and partly by some small private companies. In relatively old communities of Hanoi, according to common regulations, HSW from households

\footnotetext{
* Corresponding author e-mail: yenth59@yahoo.com
} 
is discharged daily to the collection points and then collected at a certain time everyday by URENCO workers. Part of HSW (easily recyclable waste) could be given or sold to junk-buyers before being taken to the collection points.

In many cases, food waste from households contained in plastic bags could be collected privately by URENCO workers or someone for animal feeding. In new communities, apartment buildings are normally equipped with discharge system and also, the junk-buyers are prohibited to come up to collect recyclable waste due to living- house regulations. Thus, the households discard them as non-recyclable waste (hereininafter referred to as Non.Rec), some households store them and give them to home helpers to sell for some coins as tip money. Collected MSW will be gathered at fixed places, where the waste collectors or the waste pickers can take out some remained sellable pieces. MSW will be transported by specialized trucks to the landfill site from $22 \mathrm{pm}$ to $3 \mathrm{am}$ of the following day. At landfill site, from 3am to 6am, waste pickers are allowed to take out some constituents of MSW which according to them are sellable. There are about 50 items of these wastes: feathers, hair, cattle bones, glass, tyre, dirty plastic bags, oily fruit covers, textile, some fruit seeds...and the items that junk-buyers often collect. The amount of taken out waste is about $10 \%$ of the total MSW brought to the landfill site each day (Source: URENCO Hanoi).

Additionally, electronic Solid Waste must be mentioned. This waste is often collected separately by the specialized junk man buyers with the price strongly depending on the remained value of the component parts. This waste is not comprised in this paper's objective.

\section{OBJECTIVES OF THE RESEARCH, INVESTIGATION METHODS}

\subsection{Areas selected for investigation}

Among three millions people living in Hanoi, about two millions are living in the urban area which consists of nine districts. One of the newly formed districts is Cau Giay, which is located in the north-west of the city with a population of 175.8 thousand citizens. Though originally being a suburban district, Cau Giay District is now rapidly urbanized.

Three selected resident groups located in Cau Giay district are characterized by incomes, living habits and house construction. They are:

- Nghia Tan old style apartment buildings (thereinafter referred to as NT), which were built in the late 1980s, are rented by officials, government employees, state companies workers as living-houses. The area of each apartment is about $35-45 \mathrm{~m}^{2}$. Residents living here are mostly salaried employees, the income of whom is at the middle level of the middle class of Vietnamese society. In addition, among the residents are retired civil servants, redundant officials, some of whom with small retiring pension are doing business on food serving or consumer goods selling.

- Lang Quoc te Thang Long modern apartment buildings (hereinafter referred to as LQTTL), which were built in the early 2000s, have been sold to citizens as living-houses. The area of each apartment is about $90-150 \mathrm{~m}^{2}$. The local residents are government officials, high class salaried employees, private- sector businessmen, well paid artists... who have high incomes. Most of them hire home helpers, some of them own cars.

- Yen Hoa Adjoining houses (hereininafter referred to as $\mathrm{YH}$ ), which were built in the last ten years, located in the former suburban villages that do not belong to the modern city planned areas. Most houses have small $5-10 \mathrm{~m}^{2}$ gardens. Local residents are various with the upperaverage income. They are salaried employees, small businessmen, civil servants, government retired officials with average incomes. They hold outdated views that it's better to own an area 
where they can build their own houses. That is why they accept the low quality substructure of living areas like the place where they are living when they can't afford to by villas.

\subsection{Research objects}

The research objects include two types of solid waste generated from three above-mentioned resident groups. The waste are solid waste that households daily throw off into collectors' handcarts and recyclable waste that households store for selling to junk-buyers or giving to someone to sell.

\subsection{Research methods}

It is not until some years ago that researches on Municipal Solid Waste in Vietnam started at universities and institutes. MSW generating sources are various which require the research to touch upon many differrent aspects of the issue. In addition, the research must be conducted continuously due to the ever-changing of waste quantity and quality. Besides, research methods are improved step by step with the purpose of better results.

The research methods analyzed thoroughly in paper [1] are:

- Questionnaires collecting

- Households interviewing

- Junk-buyers interviewing

- Actual samples sorting

\section{RESULTS AND DISCUSSION}

Compositions of non-recyclable HSW of studied communities were investigated and assessed; the results were shown on table 1 and 2. High percentage of food waste was recorded on LQTTL (67.68\%), where density of non-recyclable waste was detected as lowest in comparison with other communities, which can be explained by the habit of cooking. One hundred percent of the families of LQTTL are using gas for cooking while in YH and NT, coal stoves are still widely used.

Similar picture could be seen on plastic and paper wastes including multimaterial-layer film coated carton food packages including plastic, aluminium, paper...that seem to be nonrecyclable because of their unsellability to junk-buyers. High percentage of plastic waste shows a common practice of using new plastic bag for shopping, food packaging as well as HSW holding in LQTTL while plastic bags could be reused in YH and NT.

Nghia Tan (NT) is a dense community with an average of about 3,633 persons per apartment (of $35-45 \mathrm{~m}^{2}$ area). Coal stoves are still widely used in NT causing both air pollution and SW generation. Because of this, miscellaneous waste (consisting mainly coal slag) in NT (24.64\%) is relatively higher than that in LQTTL(3.6\%) and YH (11.28\%).

YH households have relatively larger living space compared to NT, where two to three family generations (4-7 persons) are living together in a house of about $100-120 \mathrm{~m}^{2}$ area. Waste generation from households (3kg/house.day) as well as food waste percentage $(58.04 \%)$ were evaluated respectively to be higher than in NT ( $2 \mathrm{~kg} /$ house.day and $52.37 \%)$.

A fact of signigicant difference on "plant/garden" (P/GW) waste (including leaves, flowers, grass...) generated in studied communities was indicated. In NT, where living space is very limited, P/GW mainly consists of market waste (food packages, banana leaves, bamboo straws...) and comprises $4.54 \%$. P/GW generation was detected as highest (7.49\%) in $\mathrm{YH}$ and 
consists of market and garden wastes (leaves, grass...). P/GW generation in LQTTL is relatively small (2.54\%) and mainly consists of flowers waste.

Textile waste (TW) generated from LQTTL, NT, YH was about $0.88 \%, 1.2 \%$ and $1.59 \%$ respectively. Low generation of TW in LQTTL could be resulted from "modern" living style, where used and unfashionable clothes would be given to the relatives living in the countrysides and old clothes are rarely used for house cleaning purpose.

The lowest generation of HSW in LQTTL in comparison with NT and YH (see tab.2) indicates a fact of living custom in LQTTL, where most of the people are "very busy" and have no time to have lunch (and dinner) at home. The highest generation and the highest density of HSW in NT could also be partly affected by the coal.

Table 1: Percentage of main compositions of non-recyclable waste of HSW.

\begin{tabular}{lrrrrrrrrr}
\hline & NT,kg & LQTTL,kg & YH,kg & Total,kg & NT, \% & $\begin{array}{c}\text { LQTTL, } \\
\text { \% }\end{array}$ & YH, \% & Aver., \% \\
\hline Paper & 5.337 & 7.245 & 9.638 & 22.220 & 9.11 & 12.86 & 8.79 & 9.8972 \\
Plastics & 3.650 & 5.234 & 9.717 & 18.601 & 6.23 & 9.29 & 8.87 & 8.2853 \\
Textiles & 0.701 & 0.498 & 1.742 & 2.941 & 1.20 & 0.88 & 1.59 & 1.3100 \\
Rubber & 0.197 & 0.015 & 0.308 & 0.520 & 0.34 & 0.03 & 0.28 & 0.2316 \\
Leather & & 0.305 & & 0.305 & 0.00 & 0.54 & 0.00 & 0.1359 \\
Glass & & 0.426 & 1.066 & 1.492 & 0.00 & 0.76 & 0.97 & 0.6646 \\
Metals & 0.445 & 0.445 & 0.227 & 1.117 & 0.76 & 0.79 & 0.21 & 0.4975 \\
Plants/Garden & 2.657 & 1.430 & 8.206 & 12.293 & 4.54 & 2.54 & 7.49 & 5.4756 \\
Wood & 0.392 & 0.470 & 1.220 & 2.082 & 0.67 & 0.83 & 1.11 & 0.9274 \\
Ceramics & 0.059 & 0.116 & 1.493 & 1.668 & 0.10 & 0.21 & 1.36 & 0.7430 \\
Food waste & 30.669 & 38.138 & 63.609 & 132.416 & 52.37 & 67.68 & 58.04 & 58.9810 \\
Miscellaneous & 14.460 & 2.027 & 12.365 & 28.852 & 24.69 & 3.60 & 11.28 & 12.8510 \\
\hline Total & $\mathbf{5 8 . 5 6 7}$ & $\mathbf{5 6 . 3 4 9}$ & $\mathbf{1 0 9 . 5 9 1}$ & $\mathbf{2 2 4 . 5 0 7}$ & 100.00 & 100.00 & 100.00 & 100.00 \\
\hline
\end{tabular}

Table 2: Flow rate of non-recyclable waste.

\begin{tabular}{lrrrrrr}
\hline & $\begin{array}{c}\text { Num.of } \\
\text { members in } \\
\text { family }\end{array}$ & $\begin{array}{c}\text { Volume/ } \\
\text { house.day,lit }\end{array}$ & $\begin{array}{c}\text { Weitgh/ } \\
\text { house.day,kg }\end{array}$ & $\begin{array}{c}\text { Volume/ } \\
\text { pers.day,lit }\end{array}$ & $\begin{array}{c}\text { Weitgh/ } \\
\text { pers.day,kg }\end{array}$ & $\begin{array}{c}\text { *Density, } \\
\mathbf{~ k g / m} \mathbf{m}^{\mathbf{3}}\end{array}$ \\
\hline NT & 3.633 & 9.700 & 2.036 & 2.670 & 0.560 & 333.0 \\
LQTTL & 4.059 & 8.529 & 1.741 & 2.101 & 0.429 & 272.9 \\
YH & 4.622 & 14.135 & 3.006 & 3.058 & 0.650 & 285.5 \\
Aver. & & & & & & 297.1 \\
\hline
\end{tabular}

Annotate: * Density of solid waste just discharged from households after sorting, before any press. 
Table 3 shows that the high percentage of paper waste in recyclable HSW was recorded in LQTTL and it can be seen that this kind of waste mainly consists of journals and newspapers. Paper bags, food boxes attached plastic film are assessed at low value in recyclable markets. Some differences in plastic waste amount from community to community were detected but they did not represent any valuable information. Plastic waste in studied areas consisted mainly PET bottles, toys, broken plastic household appliances ...etc. Contaminated by food and beverage bottles and plastic bags are discharged as non- recyclable waste.

Little amount of glass waste was seen in every community. Most of domestic standard bottles (beer, wine, beverage) are reused through dealer network. The remaining, which can not be reused (imported wine bottles, bottles for food packaging), are collected and go through further treatment as a second material source.

Metal waste was found with a lower percentage in studied areas and mainly consists of food cans, beverage bottles, broken household devices, most of which is recycled.

Table 3: Percentage of main compositions of recyclable waste.

\begin{tabular}{|c|c|c|c|c|c|c|c|c|}
\hline & $\mathrm{NT}, \mathrm{kg}$ & $\begin{array}{l}\text { LQTTL, } \\
\mathrm{kg}\end{array}$ & YH, kg & Total, kg & NT, $\%$ & $\begin{array}{l}\text { LQTTL, } \\
\%\end{array}$ & $\mathrm{YH}, \%$ & $\begin{array}{l}\text { Aver., } \\
\%\end{array}$ \\
\hline Paper & 33.530 & 30.765 & 30.477 & 94.772 & 46.169 & 62.878 & 42.647 & 49.10 \\
\hline Plastics & 21.611 & 10.955 & 23.493 & 56.059 & 29.757 & 22.390 & 32.874 & 29.04 \\
\hline \multicolumn{9}{|l|}{ Textiles } \\
\hline Rubber & 0.917 & & & & & & & \\
\hline Leather & 1.769 & & & 1.769 & & & & 0.92 \\
\hline Glass & 7.466 & 3.538 & 11.859 & 22.863 & 10.280 & 7.231 & 16.595 & 11.85 \\
\hline Metals & 7.332 & 3.670 & 5.634 & 16.636 & 10.096 & 7.501 & 7.884 & 8.62 \\
\hline \multicolumn{9}{|c|}{ Plants/Garden } \\
\hline \multicolumn{9}{|l|}{ Wood } \\
\hline \multicolumn{9}{|c|}{ Ceramics } \\
\hline \multicolumn{9}{|c|}{ Food waste } \\
\hline \multicolumn{9}{|c|}{ Miscellaneous } \\
\hline Total & 72.625 & 48.928 & 71.463 & 193.016 & 100.00 & 100.00 & 100.00 & 100.00 \\
\hline
\end{tabular}

Table 4: Flow rate of recyclable waste.

\begin{tabular}{lrrrrrr}
\hline & $\begin{array}{c}\text { Num.of } \\
\text { members in } \\
\text { family }\end{array}$ & $\begin{array}{c}\text { Volume/ } \\
\text { house.day,lit }\end{array}$ & $\begin{array}{c}\text { Weitgh/ } \\
\text { house.day,kg }\end{array}$ & $\begin{array}{c}\text { Volume/ } \\
\text { pers.day,lit }\end{array}$ & $\begin{array}{c}\text { Weitgh/ } \\
\text { pers.day,kg }\end{array}$ & $\begin{array}{c}\text { *Density, } \\
\mathbf{k g} / \mathbf{m}^{3}\end{array}$ \\
\hline NT & 3.946 & 6.089 & 0.325 & 1.543 & 0.082 & 40.225 \\
LQTTL & 3.941 & 4.151 & 0.259 & 1.053 & 0.066 & 49.199 \\
YH & 4.568 & 5.494 & 0.280 & 1.203 & 0.061 & 51.841 \\
Aver. & & & & & & 47.088 \\
\hline
\end{tabular}

Annotate: * Density of solid waste just discharged from households after sorting, before any press. 
It is obvious from table 2 and 4 that the density of non- recyclable waste is over 6 times higher than recyclable one.

The information presented in table 5 shows that the lowest (1:12.7) waste circulating rate is at the YH upper-average income group. The ratio is about 1:7.8 between recyclable and nonrecyclable waste at NT and LQTTL groups.

Table 5: Percentage of main compositions of recyclable and non-recyclable waste in total HSW.

\begin{tabular}{|c|c|c|c|c|c|c|}
\hline \multirow[b]{2}{*}{ Materials } & \multicolumn{2}{|c|}{ NT } & \multicolumn{2}{|c|}{ LQTTL } & \multicolumn{2}{|c|}{ YH } \\
\hline & Rec. & Non.Rec & Rec. & Non.Rec & Rec. & Non.Rec \\
\hline Paper & 5.416 & 8.083 & 7.123 & 11.401 & 3.132 & 8.149 \\
\hline Plastics & 3.491 & 5.528 & 2.536 & 8.236 & 2.414 & 8.216 \\
\hline Textiles & & 1.062 & & 0.784 & & 1.473 \\
\hline Rubber & & 0.298 & & 0.024 & & 0.260 \\
\hline Leather & & & & 0.480 & & \\
\hline Glass & 1.206 & & 0.819 & 0.670 & 1.219 & 0.901 \\
\hline Metals & 1.184 & 0.674 & 0.850 & 0.700 & 0.579 & 0.192 \\
\hline Plants/Garden & & 4.024 & & 2.250 & & 6.938 \\
\hline Wood & & 0.594 & & 0.740 & & 1.031 \\
\hline Ceramics & & 0.089 & & 0.183 & & 1.262 \\
\hline Food waste & & 46.450 & & 60.015 & & 53.780 \\
\hline Miscellaneous & & 21.900 & & 3.190 & & 10.454 \\
\hline Total & 11.297 & 88.703 & 11.328 & 88.672 & 7.343 & 92.657 \\
\hline
\end{tabular}

Table 6: Percentage of main compositions of HSW.

\begin{tabular}{lrrrrrrrrr}
\hline & $\begin{array}{l}\text { Total } \\
\text { NT,kg }\end{array}$ & \multicolumn{1}{c}{$\begin{array}{l}\text { Total } \\
\text { LQTTL,kg }\end{array}$} & $\begin{array}{l}\text { Total } \\
\text { YH,kg }\end{array}$ & Total,kg & NT, \% & $\begin{array}{c}\text { LQTTL, YH, \% } \\
\text { \% }\end{array}$ & $\begin{array}{l}\text { Aver., } \\
\text { \% }\end{array}$ \\
\hline Paper & 8.913 & 11.771 & 13.342 & 34.026 & 13.50 & 18.52 & 11.28 & 13.73 \\
Plastics & 5.955 & 6.846 & 12.572 & 25.373 & 9.02 & 10.77 & 10.63 & 10.24 \\
Textiles & 0.701 & 0.498 & 1.742 & 2.941 & 1.06 & 0.78 & 1.47 & 1.19 \\
Rubber & 0.197 & 0.015 & 0.308 & 0.520 & 0.30 & 0.02 & 0.26 & 0.21 \\
Leather & & 0.305 & & 0.305 & & 0.48 & & 0.12 \\
Glass & 0.796 & 0.947 & 2.507 & 4.250 & 1.21 & 1.49 & 2.12 & 1.71 \\
Metals & 1.227 & 0.985 & 0.912 & 3.124 & 1.86 & 1.55 & 0.77 & 1.26 \\
Plants/Garden & 2.657 & 1.430 & 8.206 & 12.293 & 4.02 & 2.25 & 6.94 & 4.96 \\
Wood & 0.392 & 0.470 & 1.220 & 2.082 & 0.59 & 0.74 & 1.03 & 0.84 \\
Ceramics & 0.059 & 0.116 & 1.493 & 1.668 & 0.09 & 0.18 & 1.26 & 0.67 \\
Food waste & 30.669 & 38.138 & 63.609 & 132.416 & 46.45 & 60.02 & 53.78 & 53.43 \\
Miscellaneous & 14.460 & 2.027 & 12.365 & 28.852 & 21.90 & 3.19 & 10.45 & 11.64 \\
Total & $\mathbf{6 6 . 0 2 6}$ & $\mathbf{6 3 . 5 4 7}$ & $\mathbf{1 1 8 . 2 7 6}$ & $\mathbf{2 4 7 . 8 5 0}$ & 100.00 & 100.00 & 100.00 & 100.00 \\
\hline
\end{tabular}

318 
Table 6 shows main compositions of the total HSW generated from NT, LQTTL, and YH. Some differences on every parameter of the HSW from studied sites were found and could be logically understood. In accordance with the conclusions based on table 1 and 2 analyses, table 6 shows higher percentage of paper and food waste and lower percentage of coal slag on HSW of LQTTL in comparison with others, especially with NT, where nearly contradictory pictures were observed.

Table 7 shows an overall picture on the total HSW generated from communities. It could be seen again that differences in the waste generation are heavily depended on living conditions and styles of each community.

Table 7: Flow rate of $H S W$.

\begin{tabular}{|c|c|c|c|c|c|c|}
\hline & $\begin{array}{l}\text { Num.of } \\
\text { members } \\
\text { in family }\end{array}$ & $\begin{array}{c}\text { Volume/ } \\
\text { house.day, } \\
\text { lit }\end{array}$ & $\begin{array}{c}\text { Weitgh/ } \\
\text { house.day, } \\
\text { kg }\end{array}$ & $\begin{array}{c}\text { Volume/ } \\
\text { pers.day, } \\
\text { lit }\end{array}$ & $\begin{array}{c}\text { Weitgh/ } \\
\text { pers.day, } \\
\text { kg }\end{array}$ & $\begin{array}{l}\text { *Density } \\
\text { kg/m }\end{array}$ \\
\hline NT & 3.633 & 15.789 & 2.361 & 4.213 & 0.643 & 182.7 \\
\hline LQTTL & 4.059 & 12.681 & 2.000 & 3.155 & 0.495 & 180.1 \\
\hline YH & 4.622 & 19.629 & 3.286 & 4.261 & 0.712 & 214.5 \\
\hline Aver. & & & & & & 192.4 \\
\hline
\end{tabular}

Annotate: * Density of solid waste just discharged from households after sorting, before any press

\section{CONCLUSIONS}

Flow rates of HSW per person in different resident groups are significantly different. It is lowest in high income and highest in upper- average income resident groups. Paper (most of which is newspaper) composition in recyclable waste has the highest rate in high income group. The lowest waste circulating rate was recorded in the upper-average income group. Food and beverage boxes with multimaterial-layer film coated inside, PET or NON-PET contaminated bottles, boxes, plastic bags....are not collected by junk-buyers. However, they are collected by waste pickers at landfill sites. Many households store food waste for castle feeding. In the modern apartment buildings, where waste discharge systems are equipped, the waste separation capacity is low.

According to the above-mentioned conclusions, some measures of HSW management are proposed as follows:

- The residents have been building the habit of separating household waste into recyclable and non- recyclable ones. This habit can be improved by separating the waste into some groups such as: paper, plastic, glass, metal ...due to certain requirements set by waste markets.

- Food waste separation has been done by many families and now can be popularized.

- Contaminated bottles, boxes, plastic bags... can be kept in the houses for some days. They can be collected alternatively some times per week. This can be improved if incentives such as receiving free waste baskets or reduced waste collecting fees are introduced.

- In modern apartment buildings, where waste discharge systems are installed, residents can be persuaded to separate waste by reasons concerning environment protection instead of financial benefits. 


\section{REFERENCES}

1. Kosuke Kawai, Nguyen The Dong, Nguyen thi Kim Thai, Saburo Matsui. Physical compositions of municipal solid waste and recyclable waste discharged from households in Hanoi, Vietnam. Collected Reports in full text of The 6th General Seminar of the Core University Program: "Environmental Science \& Technology for Sustainability of Asia". Osaka 2-4 October 2006.

2. Nguyen Thi Kim Thai et al. Study on forecast of environment change caused by solid waste generated during urbanization and industrialization of Hanoi. Collected Scientific Reports in full text of National Environmental Conference 1998, VEPA, MOSTE, 169-181.

3. Tuong Thi Hoi, Dang Kim Chi, Do Trong Mui. State of the art of the Plastics waste in Hanoi city. Collected Reports in full text of the International Workshop "Technology of Municipal Solid Waste Treatment - Experiences and Challenges" Hanoi, March 2003, 5360 . 